\title{
Synthesis and characterization of cationic dicarbonyl Fe(II) PNP pincer complexes
}

\author{
Mathias Glatz $^{1}$ • Christian Schröder-Holzhacker ${ }^{1} \cdot$ Bernhard Bichler $^{1}$ • \\ Berthold Stöger $^{2} \cdot$ Kurt Mereiter $^{2} \cdot$ Luis F. Veiros $^{3} \cdot$ Karl Kirchner $^{1}$
}

Received: 16 May 2016/ Accepted: 26 June 2016/Published online: 6 August 2016

(c) The Author(s) 2016. This article is published with open access at Springerlink.com

\begin{abstract}
In the present work, we have prepared a series of octahedral $\mathrm{Fe}(\mathrm{II})$ complexes of the type trans$\left[\mathrm{Fe}(\mathrm{PNP})(\mathrm{CO})_{2} \mathrm{Cl}\right]^{+}-\mathrm{PNP}$ are tridentate pincer-type ligands based on 2,6-diaminopyridine. These complexes are formed irrespective of the size of the substituents at the phosphorus sites and whether cis-[Fe( $\left.\mathrm{PNP})\left(\mathrm{Cl}_{2}\right)(\mathrm{CO})\right]$ or trans-[ $\left.\mathrm{Fe}(\mathrm{PNP})\left(\mathrm{Cl}_{2}\right)(\mathrm{CO})\right]$ are reacted with $\mathrm{CO}$ in the presence of 1 equiv of silver salts. X-ray structures of representative complexes are presented. Based on simple bonding considerations the selective formation of transdicarbonyl $\mathrm{Fe}(\mathrm{II})$ complexes is unexpected. In fact, DFT calculations confirm that trans-dicarbonyl complexes are indeed thermodynamically disfavored over the respective cis-dicarbonyl compounds, but are favored for kinetic reasons.
\end{abstract}

Karl Kirchner

kkirch@mail.tuwien.ac.at

1 Institute of Applied Synthetic Chemistry, Vienna University of Technology, Getreidemarkt 9/163, 1060 Vienna, Austria

2 Institute of Chemical Technologies and Analytics, Vienna University of Technology, Getreidemarkt 9, 1060 Vienna, Austria

3 Centro de Química Estrutural, Instituto Superior Técnico, Universidade de Lisboa, Av. Rovisco Pais No. 1, 1049-001 Lisbon, Portugal
Graphical abstract

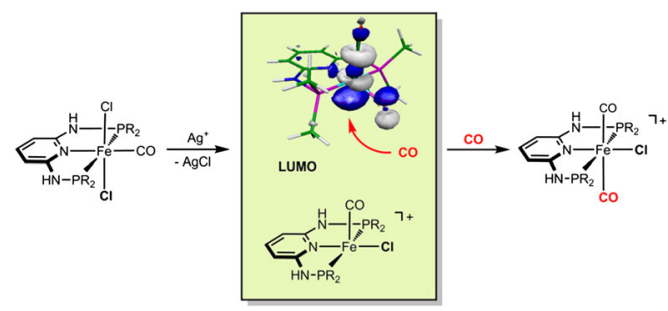

Keywords Iron complexes - PNP pincer ligands · Carbon monoxide $\cdot$ DFT calculations

\section{Introduction}

As part of our ongoing research on the synthesis and reactivity of iron(II) PNP pincer complexes [1-3], we recently prepared the cationic dicarbonyl complex trans$\left[\mathrm{Fe}(\mathrm{PNP}-i \mathrm{Pr})(\mathrm{CO})_{2} \mathrm{Cl}\right]^{+}\left(\mathrm{PNP}-i \mathrm{Pr}=N, N^{\prime}\right.$-bis(diisopropyl)2,6-diaminopyridine) (trans-2a) as shown in Scheme 1 [4]. The formation of this complex was somewhat unexpected as it features two CO ligands in a mutual trans position. In fact, simple bonding considerations suggest that the unobserved cis isomers are the more stable one. This was indeed also supported by DFT calculations. This complex is interesting, since the trans $\mathrm{CO}$ arrangement makes one of the CO ligands comparatively labile which can be replaced by other potential ligands. Accordingly, trans-[Fe(PNP$\left.i \operatorname{Pr})(\mathrm{CO})_{2} \mathrm{Cl}\right] X$ with $X=\mathrm{BF}_{4}{ }^{-}$turned out to be an efficient precatalyst for the coupling of aromatic aldehydes with ethyl diazoacetate to selectively give 3-hydroxyacrylates rather than $\beta$-keto esters [5]. 


\section{Scheme 1}

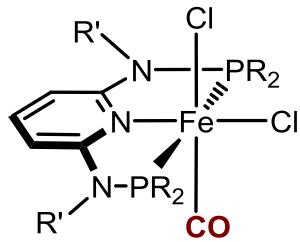

cis-1a $\mathrm{R}=i-\mathrm{Pr}, \mathrm{R}^{\prime}=\mathrm{H}$ cis-1b R $=\mathrm{Ph}, \mathrm{R}^{\prime}=\mathrm{H}$

cis-1f $\mathrm{R}=i-\mathrm{Pr}, \mathrm{R}^{\prime}=\mathrm{Me}$ cis-1g $\mathrm{R}=i-\mathrm{Pr}, \mathrm{R}^{\prime}=\mathrm{Et}$
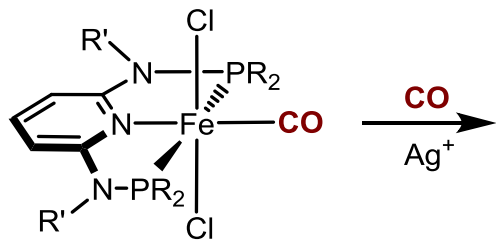

trans-1a $\mathrm{R}=i-\operatorname{Pr}, \mathrm{R}^{\prime}=\mathrm{H}$

trans-1c $\mathrm{R}=\mathrm{Me}, \mathrm{R}^{\prime}=\mathrm{H}$ trans-1d $\mathrm{R}=\mathrm{Et}, \mathrm{R}^{\prime}=\mathrm{H}$ trans-1e $\mathrm{R}=n-\mathrm{Pr}, \mathrm{R}^{\prime}=\mathrm{H}$ trans-1f $\mathrm{R}=i-\mathrm{Pr}, \mathrm{R}^{\prime}=\mathrm{Me}$ trans-1g $\mathrm{R}=i-\mathrm{Pr}, \mathrm{R}^{\prime}=\mathrm{Et}$

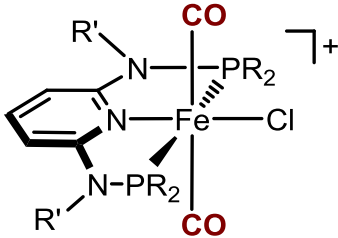

trans-2a-2g
In continuation of our studies on iron PNP complexes, we herein report on the synthesis and reactivity of a series octahedral $\mathrm{Fe}$ (II) carbonyl complexes bearing both sterically little demanding as well as bulky PNP ligands in order to probe whether sterics influences the preference for a trans- over a cis-dicarbonyl arrangement. Moreover, we investigate the impact of the NR linker on the outcome of these reactions.

\section{Results and discussion}

Treatment of complexes cis-1b and trans-1c-1g (1f and $\mathbf{1 g}$ are mixtures of cis and trans isomers) with 1 equiv of $\mathrm{Ag}^{+}$ salts (with $\mathrm{SbF}_{6}^{-}, \mathrm{BF}_{4}^{-}$, or $\mathrm{CF}_{3} \mathrm{SO}_{3}{ }^{-}$as counterions) in THF or acetone in the presence of $\mathrm{CO}$ at room temperature selectively afforded the cationic complexes trans-[Fe $\left(\kappa^{3-}\right.$ $P, N, P$-PNP) $\left.(\mathrm{CO})_{2} X\right]^{+}{ }_{\text {trans-2b-2g) }}$ in 78-98 \% isolated yields (Scheme 1). The respective cis-dicarbonyl complexes were not observed and, hence, sterics and also the amine linker (NR) apparently do not influence the preference for a trans-dicarbonyl geometry. This is also supported by DFT calculations (vide infra). These complexes are thermally robust red solids that are air stable both in the solid state and in solution for several days. Characterization was accomplished by elemental analysis and ${ }^{1} \mathrm{H},{ }^{13} \mathrm{C}\left\{{ }^{1} \mathrm{H}\right\},{ }^{31} \mathrm{P}\left\{{ }^{1} \mathrm{H}\right\}$ NMR and IR spectroscopy. In addition, the solid state structures of trans- $\mathbf{2 b}$, trans-2d, trans-2f, and trans-2g were determined by singlecrystal X-ray diffraction.

In the IR spectrum, as expected, the CO ligands exhibit only one band between 1979 and $2031 \mathrm{~cm}^{-1}$ for the mutually trans CO ligands which are assigned to the asymmetric $\mathrm{CO}$ stretching frequency. The symmetric $\mathrm{CO}$ stretching band is IR inactive and not observed. The ${ }^{31} \mathrm{P}\left\{{ }^{1} \mathrm{H}\right\}$ NMR spectrum of complexes trans-2b-2g show singlet resonances at 85.0, 92.3, 100.7, 96.7, 130.6, and $132.8 \mathrm{ppm}$, respectively. In the ${ }^{13} \mathrm{C}\left\{{ }^{1} \mathrm{H}\right\}$ NMR spectrum the two $\mathrm{CO}$ ligands exhibit a single low-intensity triplet resonance in the range of 207.2-211.8 ppm, thus clearly revealing that the two $\mathrm{CO}$ ligands are trans to one another.

Structural views of trans-2b, trans-2d, trans-2f, and trans-2g are depicted in Figs. 1, 2, 3 and 4 with selected bond distances and angles reported in the captions. All complexes adopt a distorted octahedral geometry around the metal center with the $\mathrm{CO}$ ligands in trans position to one another. The PNP ligand is coordinated to the iron center in a typical tridentate meridional mode, with $\mathrm{P}-\mathrm{Fe}-\mathrm{P}$ angles between $167.8^{\circ}$ and $169.1^{\circ}$. The $\mathrm{C}_{(\mathrm{CO})}-\mathrm{Fe}-\mathrm{C}_{(\mathrm{CO})}$ angles vary between $168.7^{\circ}$ and $174.4^{\circ}$. The compounds with $\mathrm{NH}$ linkers show, as a typical feature, hydrogen bonds between the $\mathrm{NH}$-groups of the cationic $\mathrm{Fe}(\mathrm{PNP})$ complexes and the counterions $\mathrm{BF}_{4}{ }^{-}$and $\mathrm{CF}_{3} \mathrm{SO}_{3}{ }^{-}$.

To better understand why trans-dicarbonyl complexes are preferred over cis-dicarbonyl complexes, DFT calculations were performed with the $N^{2}, N^{6}$ bis(dimethylphosphanyl)-pyridine-2,6-diamine ligand (PNP-Me) as model. The starting point of our calculations are the coordinatively unsaturated cationic intermediates $[\mathrm{Fe}(\mathrm{PNP}-\mathrm{Me})(\mathrm{CO}) \mathrm{Cl}]^{+}(\mathbf{A}$ and/or $\mathbf{B})$, which are formed from trans-[Fe( $\left(\kappa^{3} P, N, P\right.$-PNP-Me $\left.)(\mathrm{CO}) \mathrm{Cl}_{2}\right] \quad$ (trans-1c) upon irreversible removal of chloride with silver salts (Scheme 2). The analogous cis isomer is experimentally not accessible. The energy profile (DFT/OPBE) for the cis/trans isomerization of $[\mathrm{Fe}(\mathrm{PNP}-\mathrm{Me})(\mathrm{CO}) \mathrm{Cl}]^{+}$is shown in Fig. 5.

According to the calculations both cationic pentacoordinated intermediates $\mathbf{A}$ and $\mathbf{B}$ adopt a square pyramidal geometry where the $\mathrm{Cl}$ and the $\mathrm{CO}$ ligands, respectively, are in the apical position. The singlet ground state ${ }^{\mathbf{1}} \mathbf{B}$ is the energetically favored species by 22.6 and $50.7 \mathrm{~kJ} \mathrm{~mol}^{-1}$, respectively, over the singlet and triplet states of $\mathbf{A}\left({ }^{\mathbf{1}} \mathbf{A}\right.$, ${ }^{\mathbf{3}} \mathbf{A}$ ) (Fig. 5). In the case of $\mathbf{B}$, no stable triplet state was found. $\mathbf{A}$ and $\mathbf{B}$ were found to interconvert readily via two pathways. ${ }^{\mathbf{1}} \mathbf{A}$ is able to isomerize along the spin singlet surface $(S=0)$ to give ${ }^{\mathbf{1}} \mathbf{B}$ with a small energy barrier of $11.3 \mathrm{~kJ} \mathrm{~mol}^{-1}$. This reaction proceeds via transition state ${ }^{1} \mathbf{T S}$ AB. In the second pathway, ${ }^{\mathbf{1}} \mathbf{A}$ undergoes two 


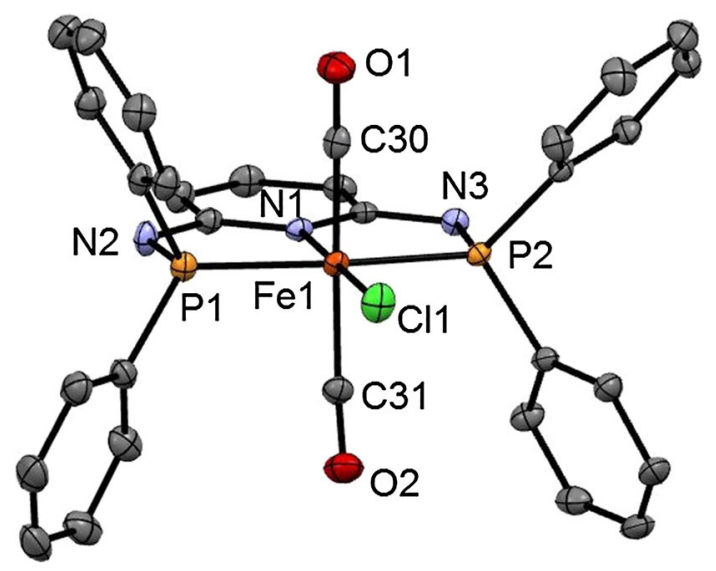

Fig. 1 Structural view of trans-[Fe( $\left.\mathrm{PNP}-\mathrm{Ph})(\mathrm{CO})_{2} \mathrm{Cl}\right] \mathrm{SbF}_{6}$ (trans2a) showing $50 \%$ thermal ellipsoids $(\mathrm{H}$ atoms and counterion omitted for clarity). Selected bond lengths $(\AA)$ and bond angles $\left({ }^{\circ}\right)$ : Fe1-Cl1 2.3029(7), Fe1-P2 2.2190(7), Fe1-P1 2.2317(7), Fe1-C30 1.824(3), Fe1-C31 1.850(3), Fe1-N1 1.977(2), P2-Fe1-P1 168.33(3), C30-Fe1-C31 172.6(1)

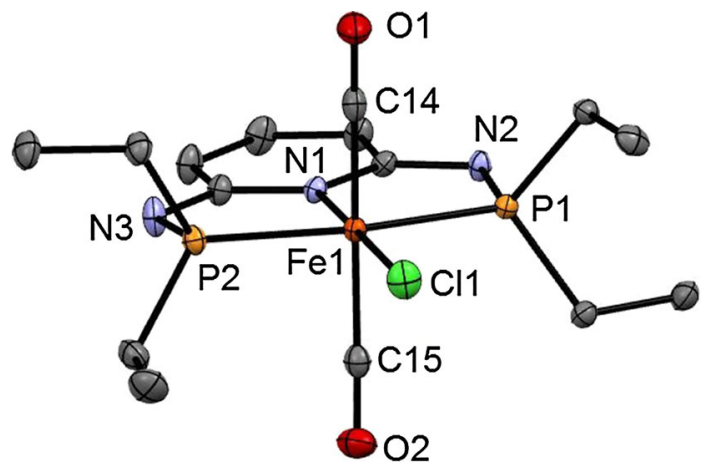

Fig. 2 Structural view of trans-[Fe(PNP-Et) $\left.(\mathrm{CO})_{2} \mathrm{Cl}_{2}\right] \mathrm{CF}_{3} \mathrm{SO}_{3}$ (trans2c) showing $50 \%$ thermal ellipsoids ( $\mathrm{H}$ atoms and counterion omitted for clarity). Selected bond lengths $(\AA)$ and bond angles $\left({ }^{\circ}\right)$ : Fe $1-\mathrm{Cl} 1$ 2.3116(4), Fe1-P1 2.2265(4), Fe1-P2 2.2302(4), Fe1-N1 1.983(1), Fe1-C14 1.823(1), Fe1-C15 1.837(1), P1-Fe1-P2 167.82(2), C14$\mathrm{Fe} 1-\mathrm{C} 15$ 172.15(6)

consecutive spin state changes (spin crossover) from $S=0$ to $S=1$ and back to $S=0$. The minimum energy crossing point ${ }^{1}$ between the potential energy surfaces of the two spin states $S=0$ to $S=1$ (CP2) is easily accessible lying merely $1.3 \mathrm{~kJ} \mathrm{~mol}^{-1}$ above ${ }^{\mathbf{1}} \mathbf{A}$. The second spin state change from $S=1$ to $S=0$ proceeds via CP1 with a barrier of $19.3 \mathrm{~kJ} \mathrm{~mol}^{-1}$.

\footnotetext{
${ }^{1}$ In the MECP both the energy as well as the geometry of the molecule are the same in the two spin states surfaces. Once that point (MECP) is reached, following the reaction coordinate, there is a given probability for the system to change spin state and hop from one PES to the other, giving rise to the "spin-forbidden" reaction. For more information about MECP and the kinetics of spin-forbidden reactions see for example Ref. [6].
}

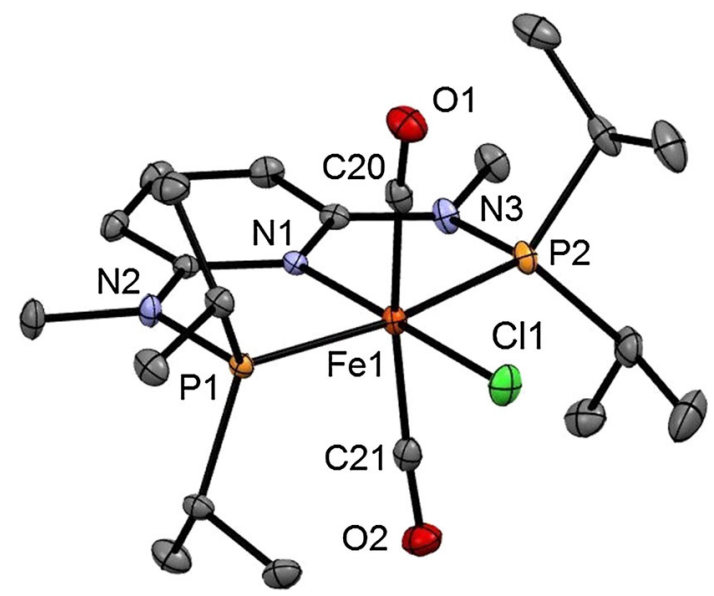

Fig. 3 Structural view of trans-[Fe( $\left.\left(\mathrm{PNP}^{\mathrm{Me}}-i \mathrm{Pr}\right)(\mathrm{CO})_{2} \mathrm{Cl}_{3}\right] \mathrm{BF}_{4}$ (trans2e) showing $50 \%$ thermal ellipsoids (H atoms and counterion omitted for clarity). Selected bond lengths $(\AA)$ and bond angles $\left({ }^{\circ}\right)$ : $\mathrm{Fe} 1-\mathrm{Cl} 1$ 2.3009(5), Fe1-P1 2.2507(5), Fe1-P2 2.2455(5), Fe1-N1 1.976(1), Fe1-C20 1.818(1), Fe1-C21 1.819(1), P1-Fe1-P2 168.33(2), C20$\mathrm{Fe} 1-\mathrm{C} 21$ 168.71(7)

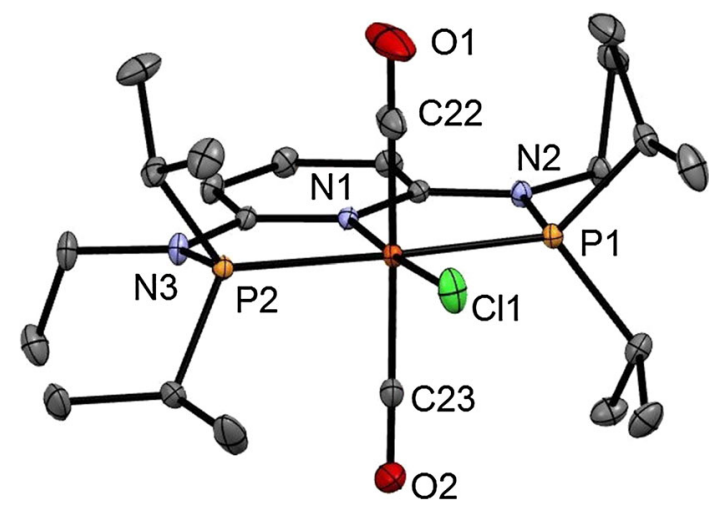

Fig. 4 Structural view of trans-[Fe( $\left.\left.\mathrm{PNP}^{\mathrm{Et}}-i \mathrm{Pr}\right)(\mathrm{CO})_{2} \mathrm{Cl}\right] \mathrm{BF}_{4}$ (trans2f) showing $50 \%$ thermal ellipsoids ( $\mathrm{H}$ atoms and counterion omitted for clarity). Selected bond lengths $(\AA)$ and bond angles $\left({ }^{\circ}\right)$ : Fe1-Cl1 2.3034(3), Fe1-P1 2.2494(3), Fe1-P2 2.2598(3), Fe1-N1 1.9713(7), Fe1-C22 1.8126(10), Fe1-C23 1.8316(8), P1-Fe1-P2 169.14(1), $\mathrm{C} 22-\mathrm{Fe} 1-\mathrm{C} 23$ 174.40(5)

Finally, the experimentally isolated trans-2c (which is actually is less stable than cis-2c by $17.2 \mathrm{~kJ} \mathrm{~mol}^{-1}$ ) is formed by an essentially barrierless addition of $\mathrm{CO}$ to ${ }^{\mathbf{1}} \mathbf{B}$ which is the most stable and predominant species lying $50.7 \mathrm{~kJ} \mathrm{~mol}^{-1}$ lower in energy than ${ }^{\mathbf{1}} \mathbf{A}$. In general, CO addition at singlet intermediates is generally more favorable than at triplet intermediates as can be seen by examining the frontier orbitals of the relevant species. The LUMO of the pentacoordinated intermediates with a singlet spin state $\left({ }^{\mathbf{1}} \mathbf{A}\right.$ and $\left.{ }^{\mathbf{1}} \mathbf{B}\right)$ are formed mainly by $z^{2}$-type orbitals centered at the Fe-atom and pointing towards the empty coordination position (Fig. 5). Therefore, these orbitals are ready to receive a pair of electrons from a ligand that occupies the sixth coordination site ( $\mathrm{CO}$ in this 
Scheme 2

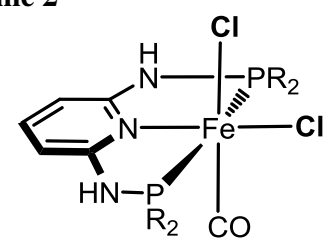

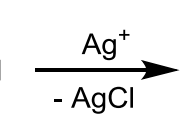

cis-1

$\mathrm{R}=\mathrm{Me}$

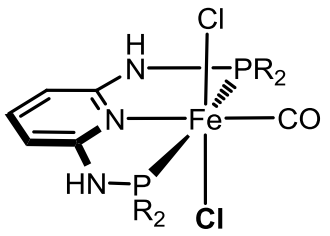

trans-1

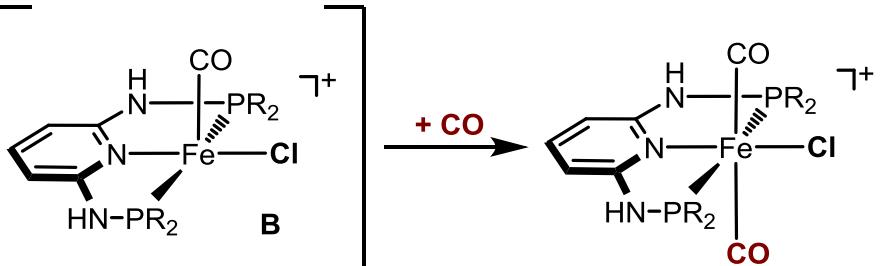

trans-2

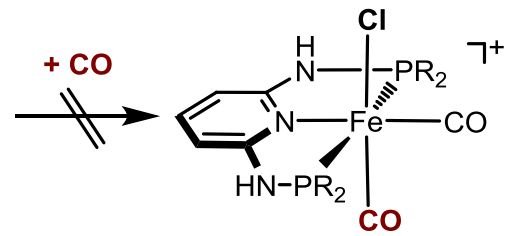

cis-2

not observed

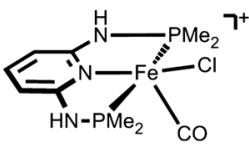

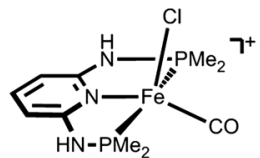

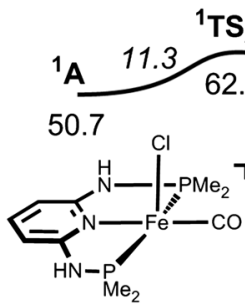

${ }^{1} S_{A B}$

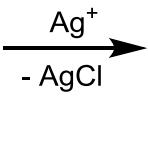

$-\mathrm{AgCl}$

$\mathrm{Ag}^{+}$

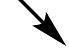

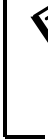

$\mathrm{HN}-\mathrm{P}_{2}$
$\mathrm{R}_{2}$

(1) 


\section{Conclusion}

In the present work we have prepared, spectroscopically and structurally characterized several octahedral iron(II) complexes of the type trans-[Fe(PNP) $\left.(\mathrm{CO})_{2} X\right]^{+}$. These complexes are formed irrespective of the size of the substituents at the phosphorus sites and whether cis$\left[\mathrm{Fe}(\mathrm{PNP})\left(\mathrm{Cl}_{2}\right)(\mathrm{CO})\right]$ or trans-[Fe( $\left.\left.\mathrm{PNP}\right)\left(\mathrm{Cl}_{2}\right)(\mathrm{CO})\right]$ are reacted with $\mathrm{CO}$ in the presence of 1 equiv of silver salts. Based on simple bonding considerations the selective formation of trans-dicarbonyl Fe(II) complexes is unexpected. DFT calculations indeed confirm that trans-dicarbonyl complexes are thermodynamically disfavored over the respective cisdicarbonyl compounds. The key to an understanding of this unexpected selectivity is the fact that upon irreversible removal of a chloride ligand from $\left[\mathrm{Fe}(\mathrm{PNP})(\mathrm{CO}) \mathrm{Cl}_{2}\right]$ pentacoordinate intermediates $[\mathrm{Fe}(\mathrm{PNP})(\mathrm{CO}) \mathrm{Cl}]^{+}$of two conformations, one with the chloride in the apical and $\mathrm{CO}$ in the basal position (A) and vice versa $(\mathbf{B})$, are formed. The subsequent carbonylation process depends strongly on the complex geometry of the 16e intermediates $[\mathrm{Fe}(\mathrm{PNP})(\mathrm{CO}) \mathrm{Cl}]^{+}$, i.e., A vs. B, which in turn determines the spin state $(S=0$ or $S=1$ ) and consequently the reactivity and also the stability of these intermediates. According to calculations, $\mathbf{B}$ in the singlet ground state is the most stable and also kinetically the most accessible intermediate in solution. The formation of trans- $\left[\mathrm{Fe}(\mathrm{PNP})(\mathrm{CO})_{2} \mathrm{Cl}\right]^{+}$is kinetically controlled with ${ }^{\mathbf{1}} \mathbf{B}$ being the key intermediate. The mechanism deduced from DFT calculations is in full agreement with experimental findings.

\section{Experimental}

All manipulations were performed under an inert atmosphere of argon by using Schlenk techniques or in an MBraun inert-gas glovebox. The solvents were purified according to standard procedures [7]. The deuterated solvents were purchased from Aldrich and dried over $4 \AA$ molecular sieves. Complexes cis-[Fe( $\kappa^{3} P, N, P$-PNP$\left.\mathrm{Ph})(\mathrm{CO}) \mathrm{Cl}_{2}\right]$ (cis-1b), trans-[Fe( $\left.\left.\kappa^{3} P, N, P-\mathrm{PNP}-\mathrm{Me}\right)(\mathrm{CO}) \mathrm{Cl}_{2}\right]$ (trans-1c), trans-[Fe $\left.\left(\kappa^{3} P, N, P-\mathrm{PNP}-\mathrm{Et}\right)(\mathrm{CO}) \mathrm{Cl}_{2}\right]$ (trans-1d), trans-[Fe $\left.\left(\kappa^{3} P, N, P-\mathrm{PNP}-n \mathrm{Pr}\right)(\mathrm{CO}) \mathrm{Cl}_{2}\right]$ (trans-1e), cis/trans$\left[\mathrm{Fe}\left(\mathrm{PNP}^{\mathrm{Me}}-i \mathrm{Pr}\right)(\mathrm{CO}) \mathrm{Cl}_{2}\right] \quad$ (cis/trans-1f), and cis/trans$\left[\mathrm{Fe}\left(\mathrm{PNP}^{\mathrm{Et}}-i \mathrm{Pr}\right)(\mathrm{CO}) \mathrm{Cl}_{2}\right] \quad$ (cis/trans-1 g) were prepared according to the literature [8]. ${ }^{1} \mathrm{H},{ }^{13} \mathrm{C}\left\{{ }^{1} \mathrm{H}\right\}$, and ${ }^{31} \mathrm{P}\left\{{ }^{1} \mathrm{H}\right\}$ NMR spectra were recorded on Bruker AVANCE-250 and AVANCE-400 spectrometers. ${ }^{1} \mathrm{H}$ and ${ }^{13} \mathrm{C}\left\{{ }^{1} \mathrm{H}\right\}$ NMR spectra were referenced internally to residual protio-solvent and solvent resonances, respectively, and are reported relative to tetramethylsilane $(\delta=0 \mathrm{ppm}) .{ }^{31} \mathrm{P}\left\{{ }^{1} \mathrm{H}\right\}$ NMR spectra were referenced externally to $\mathrm{H}_{3} \mathrm{PO}_{4}(85 \%)(\delta=0 \mathrm{ppm})$.
Trans-[(chloro) $\left[N^{2}, N^{6}\right.$-bis(diphenylphosphanyl)pyridine2,6-diamine](dicarbonyl)iron(II)] tetrafluoroborate (trans- $\left[\mathrm{Fe}\left(\kappa^{3} \mathrm{P}, \mathrm{N}, \mathrm{P}-\mathrm{PNP}-\mathrm{Ph}\right)(\mathrm{CO})_{2} \mathrm{Cl}_{\mathrm{B}} \mathrm{BF}_{4}\right)$ (trans-2b, $\mathrm{C}_{31} \mathrm{H}_{25} \mathrm{BClF}_{4} \mathrm{FeN}_{3} \mathrm{O}_{2} \mathrm{P}_{2}$ )

Complex cis-1b (200 mg, $0.316 \mathrm{mmol}$ ) was dissolved in $10 \mathrm{~cm}^{3}$ THF, CO gas was bubbled through the solution and $62 \mathrm{mg} \mathrm{AgBF}_{4}(0.316 \mathrm{mmol})$ was added. After $4 \mathrm{~h}$ the red solution was filtered over Celite and the solvent was evaporated. The red powder was washed with $20 \mathrm{~cm}^{3} \mathrm{Et}_{2} \mathrm{O}$ and dried under vacuum. Yield $180 \mathrm{mg}(85 \%) ;{ }^{1} \mathrm{H}$ NMR (acetone- $\left.d_{6}, 20^{\circ} \mathrm{C}\right): \delta=9.50(\mathrm{~s}, 2 \mathrm{H}, \mathrm{NH}), 8.10(\mathrm{~m}, 5 \mathrm{H}$, $\left.\mathrm{Ph}, \mathrm{py}^{4}\right), 7.71\left(\mathrm{~m}, 18 \mathrm{H}, \mathrm{Ph}, \mathrm{py}^{3,5}\right) \mathrm{ppm} ;{ }^{13} \mathrm{C}\left\{{ }^{1} \mathrm{H}\right\} \mathrm{NMR}$ $\left(\mathrm{CD}_{2} \mathrm{Cl}_{2}\right): \delta=207.2(\mathrm{t}, J=25.8 \mathrm{~Hz}, \mathrm{CO}), 161.3$ (py), 141.8 (py), 134.6-133.2 (Ph), $132.10(\mathrm{Ph}), 131.0-129.8$ (Ph), 129.2 (t, $J=5.4 \mathrm{~Hz}, \mathrm{Ph}), 102.2$ (py) ppm; ${ }^{31} \mathrm{P}\left\{{ }^{1} \mathrm{H}\right\}$ NMR (acetone- $d_{\sigma}, 20{ }^{\circ} \mathrm{C}$ ): $\delta=85.0 \mathrm{ppm}$; IR (ATR, $\left.20{ }^{\circ} \mathrm{C}\right): \bar{v}=2031\left(v_{\mathrm{C}=\mathrm{O}}\right) \mathrm{cm}^{-1}$.

Trans-[(chloro) $\left[N^{2}, N^{6}\right.$-bis(dimethylphosphanyl)pyridine2,6-diamine](dicarbonyl)iron(II)] trifluoromethanesulfonate (trans- $\left[\mathrm{Fe}\left(\kappa^{3} \mathrm{P}, \mathrm{N}, \mathrm{P}-\mathrm{PNP}-\mathrm{Me}\right)(\mathrm{CO})_{2} \mathrm{Cl}_{\mathrm{C}} \mathrm{CF}_{3} \mathrm{SO}_{3}\right.$ )

(trans-2c, $\mathrm{C}_{12} \mathrm{H}_{17} \mathrm{ClF}_{3} \mathrm{FeN}_{3} \mathrm{O}_{5} \mathrm{P}_{2} \mathrm{~S}$ )

$\mathrm{CO}$ was bubbled through a suspension of $100 \mathrm{mg}$ trans-1b $(0.26 \mathrm{mmol})$ and $67 \mathrm{mg} \mathrm{AgCF} \mathrm{SO}_{3}(0.26 \mathrm{mmol})$ in $7 \mathrm{~cm}^{3}$ acetone. The orange solution was then filtrated over Celite, evaporated to dryness and the obtained solid was washed with $10 \mathrm{~cm}^{3} n$-hexane. The orange powder was dried under reduced pressure. Yield $134 \mathrm{mg}(98 \%) ;{ }^{1} \mathrm{H}$ NMR (acetone$\left.d_{6}, 20{ }^{\circ} \mathrm{C}\right): \delta=8.46(\mathrm{~s}, 2 \mathrm{H}, \mathrm{NH}), 7.33\left(\mathrm{t}, J_{H H}=7.9 \mathrm{~Hz}\right.$, $\left.1 \mathrm{H}, \mathrm{py}^{4}\right), 6.23\left(\mathrm{~d}, J_{H H}=8.0 \mathrm{~Hz}, 2 \mathrm{H}, \mathrm{py}^{3,5}\right), 2.38(\mathrm{~m}, 12 \mathrm{H}$, $\left.\mathrm{CH}_{3}\right)$ ppm; ${ }^{13} \mathrm{C}\left\{{ }^{1} \mathrm{H}\right\}$ NMR (acetone- $d_{6}, 20{ }^{\circ} \mathrm{C}$ ): $\delta=210.3$ $\left(\mathrm{t}, J_{C P}=26.8 \mathrm{~Hz}, \mathrm{CO}\right), 162.4\left(\mathrm{t}, J_{C P}=7.5 \mathrm{~Hz}, \mathrm{py}\right), 141.9$ (py), $101.1\left(\mathrm{t}, J_{C P}=3.8 \mathrm{~Hz}, \mathrm{py}\right), 18.9\left(\mathrm{t}, J_{C P}=17.2 \mathrm{~Hz}\right.$, $\left.\mathrm{CH}_{3}\right) \quad \operatorname{ppm} ; \quad{ }^{31} \mathrm{P}\left\{{ }^{1} \mathrm{H}\right\} \quad \mathrm{NMR} \quad$ (acetone- $\left.d_{6}, \quad 20{ }^{\circ} \mathrm{C}\right)$ : $\delta=92.3$ ppm; IR (ATR): $\bar{v}=1979\left(v_{\mathrm{CO}}\right) \mathrm{cm}^{-1}$.

Trans-[(chloro) $\left[N^{2}, N^{6}\right.$-bis(diethylphosphanyl)pyridine-2,6diamine](dicarbonyl)iron(II)] trifluoromethanesulfonate (trans- $\left[\mathrm{Fe}\left(\kappa^{3} \mathrm{P}, \mathrm{N}, \mathrm{P}-\mathrm{PNP}-\mathrm{Et}\right)(\mathrm{CO})_{2} \mathrm{Cl} \mathrm{CF}_{3} \mathrm{SO}_{3}\right)$

(trans-2c, $\mathrm{C}_{16} \mathrm{H}_{25} \mathrm{ClF}_{3} \mathrm{FeN}_{3} \mathrm{O}_{5} \mathrm{P}_{2} \mathrm{~S}$ )

This compound was prepared analogously to trans-2b with $120 \mathrm{mg}$ trans $-1 \mathrm{c}(0.27 \mathrm{mmol})$ and $70 \mathrm{mg} \quad \mathrm{AgCF}_{3} \mathrm{SO}_{3}$ $(0.27 \mathrm{mmol})$ as starting materials. The orange product was dried under reduced pressure. Yield: $153 \mathrm{mg}$ (97\%). Crystals were grown from an acetone solution of 2c by slow diffusion of $\mathrm{Et}_{2} \mathrm{O} .{ }^{1} \mathrm{H}$ NMR (acetone- $d_{6}, 20{ }^{\circ} \mathrm{C}$ ): $\delta=8.49(2 \mathrm{H}, \mathrm{NH}), 7.63\left(1 \mathrm{H}, \mathrm{py}^{4}\right), 6.31\left(\mathrm{~d}, J_{H H}=5.2 \mathrm{~Hz}\right.$, $\left.2 \mathrm{H}, \mathrm{py}^{3,5}\right), 2.90\left(4 \mathrm{H}, \mathrm{CH}_{2}\right), 2.78\left(4 \mathrm{H}, \mathrm{CH}_{2}\right), 1.51(12 \mathrm{H}$, $\mathrm{CH}_{3}$ ) ppm; ${ }^{13} \mathrm{C}\left\{{ }^{1} \mathrm{H}\right\}$ NMR (acetone- $d_{6}, 20{ }^{\circ} \mathrm{C}$ ): $\delta=210.5$ $\left(\mathrm{t}, J_{C P}=25.2 \mathrm{~Hz}, \mathrm{CO}\right), 161.8\left(\mathrm{t}, J_{C P}=6.9 \mathrm{~Hz}, \mathrm{py}\right), 141.1$ (py), 100.3 (py), 23.4 (t, $\left.J_{C P}=15.3 \mathrm{~Hz}, \mathrm{CH}_{2}\right), 6.4\left(\mathrm{CH}_{3}\right)$ ppm; ${ }^{31} \mathrm{P}\left\{{ }^{1} \mathrm{H}\right\}$ NMR (acetone- $d_{6}, 20{ }^{\circ} \mathrm{C}$ ): $\delta=100.7 \mathrm{ppm}$; IR (ATR): $\bar{v}=2008\left(v_{\mathrm{CO}}\right) \mathrm{cm}^{-1}$. 
Trans-[(chloro) $\left[N^{2}, N^{6}\right.$-bis(dipropylphosphanyl)pyridine2,6-diamine](dicarbonyl)iron(II)] trifluoromethanesulfonate (trans- $\left[\mathrm{Fe}\left(\kappa^{3} \mathrm{P}, \mathrm{N}, \mathrm{P}-\mathrm{PNP}-\mathrm{nPr}\right)(\mathrm{CO})_{2} \mathrm{Cl} \mathrm{CF}_{3} \mathrm{SO}_{3}\right.$ ) (trans-2d, $\mathrm{C}_{20} \mathrm{H}_{33} \mathrm{ClF}_{3} \mathrm{FeN}_{3} \mathrm{O}_{5} \mathrm{P}_{2} \mathrm{~S}$ )

This compound was prepared analogously to trans-2b using $150 \mathrm{mg}$ trans $-\mathbf{1 d}(0.30 \mathrm{mmol})$ and $78 \mathrm{mg} \mathrm{AgCF} \mathrm{SO}_{3}$ $(0.30 \mathrm{mmol})$ as starting materials. The red-orange product was dried under reduced pressure. Yield: $177 \mathrm{mg}$ (92\%); ${ }^{1} \mathrm{H}$ NMR (acetone- $\left.d_{6}, 20{ }^{\circ} \mathrm{C}\right): \delta=8.41(2 \mathrm{H}, \mathrm{NH}), 7.47(\mathrm{t}$, $\left.J_{H H}=7.9 \mathrm{~Hz}, 1 \mathrm{H}, \mathrm{py}^{4}\right), 6.41\left(\mathrm{~d}, J_{H H}=7.6 \mathrm{~Hz}, 2 \mathrm{H}, \mathrm{py}^{2,6}\right)$, $2.01\left(\mathrm{~m}, 8 \mathrm{H}, \mathrm{CH}_{2}\right), 1.58\left(\mathrm{~m}, 8 \mathrm{H}, \mathrm{CH}_{2}\right), 1.12(\mathrm{t}$, $\left.J_{H H}=7.1 \mathrm{~Hz}, 12 \mathrm{H}, \mathrm{CH}_{3}\right) \mathrm{ppm} ;{ }^{13} \mathrm{C}\left\{{ }^{1} \mathrm{H}\right\}$ NMR (acetone$\left.d_{6}, 20^{\circ} \mathrm{C}\right): \delta=210.4\left(\mathrm{t}, J_{C P}=25.6 \mathrm{~Hz}, \mathrm{CO}\right), 161.7(\mathrm{t}$, $\left.J_{C P}=6.8 \mathrm{~Hz}, \mathrm{py}\right), 140.9$ (py), $100.2\left(\mathrm{t}, J_{C P}=3.7 \mathrm{~Hz}, \mathrm{py}\right)$, $32.8\left(\mathrm{t}, \quad J_{C P}=14.3 \mathrm{~Hz}, \mathrm{CH}_{2}\right), 16.2\left(\mathrm{CH}_{3}\right), 15.0 \quad(\mathrm{t}$, $J_{C P}=7.8 \mathrm{~Hz}, \mathrm{CH}_{2}$ ) ppm; ${ }^{31} \mathrm{P}\left\{{ }^{1} \mathrm{H}\right\}$ NMR (acetone- $d_{6}$, $\left.20{ }^{\circ} \mathrm{C}\right): \delta=96.7 \mathrm{ppm}$; IR (ATR): $\bar{v}=2011\left(v_{\mathrm{CO}}\right) \mathrm{cm}^{-1}$.

Trans-[(chloro) $\left[N^{2}, N^{6}\right.$-bis(diisopropylphosphanyl) $-N^{2}, N^{6}$ dimethylpyridine-2,6-diamine](dicarbonyl)iron(II)] tetrafluoroborate (trans- $\left[\mathrm{Fe}\left(\kappa^{3} \mathrm{P}, \mathrm{N}, \mathrm{P}-\mathrm{PNP} \mathrm{Pe}_{-} \mathrm{iPr}\right.\right.$ ) $(\mathrm{CO})_{2} \mathrm{ClJBF}_{4}$ ) (trans-2e, $\mathrm{C}_{21} \mathrm{H}_{37} \mathrm{BClF}_{4} \mathrm{FeN}_{3} \mathrm{O}_{2} \mathrm{P}_{2}$ )

$\mathrm{CO}$ was bubbled through a solution of $150 \mathrm{mg}$ cis/trans-1e $(0.30 \mathrm{mmol})$ and $59 \mathrm{mg} \mathrm{AgBF} 4(0.30 \mathrm{mmol})$ in $15 \mathrm{~cm}^{3}$ of THF. The pink solution was stirred under $\mathrm{CO}$ atmosphere for $1 \mathrm{~h}$; then the solvent was removed under reduced pressure. The residue was redissolved in $15 \mathrm{~cm}^{3}$ of $\mathrm{CH}_{2} \mathrm{Cl}_{2}$, filtered and the volume of the solvent was reduced to about $0.5 \mathrm{~cm}^{3}$. The product was precipitated by addition of $40 \mathrm{~cm}^{3}$ of pentane, collected on a glass frit, washed with $15 \mathrm{~cm}^{3}$ of $n$-pentane, and dried under vacuum. Yield: $141 \mathrm{mg}(78 \%) ;{ }^{1} \mathrm{H}$ NMR $\left(\mathrm{CD}_{2} \mathrm{Cl}_{2}, 20{ }^{\circ} \mathrm{C}\right): \delta=7.53(\mathrm{t}$, $\left.{ }^{3} J_{H H}=8.1 \mathrm{~Hz}, 1 \mathrm{H}, \mathrm{py}^{4}\right), 6.14\left(\mathrm{~d},{ }^{3} J_{H H}=8.2 \mathrm{~Hz}, 2 \mathrm{H}\right.$, $\left.\mathrm{py}^{3,5}\right), 3.19$ (m, $\left.4 \mathrm{H}, \mathrm{CH}\left(\mathrm{CH}_{3}\right)_{2}\right), 3.08\left(\mathrm{~s}, 6 \mathrm{H}, \mathrm{NCH}_{3}\right), 1.53-$ $1.42\left(\mathrm{~m}, 24 \mathrm{H}, \mathrm{CH}\left(\mathrm{CH}_{3}\right)_{2}\right) \mathrm{ppm} ;{ }^{13} \mathrm{C}\left\{{ }^{1} \mathrm{H}\right\}$ NMR $\left(\mathrm{CD}_{2} \mathrm{Cl}_{2}\right.$, $\left.20{ }^{\circ} \mathrm{C}\right): \delta=211.6\left(\mathrm{t},{ }^{2} J_{C P}=24.7 \mathrm{~Hz}, \mathrm{CO}\right), 163.0$ (vt, $\left.{ }^{2} J_{C P}=7.4 \mathrm{~Hz}, \quad \mathrm{py}^{2,6}\right), \quad 142.2 \quad\left(\mathrm{~s}, \quad \mathrm{py}^{4}\right), \quad 100.2 \quad(\mathrm{vt}$, $\left.{ }^{3} J_{C P}=2.7 \mathrm{~Hz}, \quad \mathrm{py}^{3,5}\right), \quad 35.4 \quad\left(\mathrm{~s}, \quad \mathrm{NCH}_{3}\right), \quad 32.0 \quad(\mathrm{vt}$, $\left.{ }^{1} J_{C P}=11.2 \mathrm{~Hz}, \mathrm{CH}\left(\mathrm{CH}_{3}\right)_{2}\right), 18.5\left(\mathrm{~s}, \mathrm{CH}\left(\mathrm{CH}_{3}\right)_{2}\right), 17.7$ (s, $\left.\mathrm{CH}\left(\mathrm{CH}_{3}\right)_{2}\right) \quad$ ppm; ${ }^{31} \mathrm{P}\left\{{ }^{1} \mathrm{H}\right\} \quad \mathrm{NMR} \quad\left(\mathrm{CD}_{2} \mathrm{Cl}_{2}, \quad 20{ }^{\circ} \mathrm{C}\right)$ : $\delta=130.6 \mathrm{ppm}$; IR (ATR): $\bar{v}=2002\left(v_{\mathrm{C}=\mathrm{O}}\right) \mathrm{cm}^{-1}$.

Trans-[(chloro) $\left[N^{2}, N^{6}\right.$-bis(diisopropylphosphanyl) $-N^{2}, N^{6}$ diethylpyridine-2,6-diamine](dicarbonyl)iron(II)] tetrafluoroborate (trans- $\left[\mathrm{Fe}\left(\kappa^{3} \mathrm{P}, \mathrm{N}, \mathrm{P}-\mathrm{PN} \mathrm{P}^{\mathrm{Et}}-\mathrm{iPr}\right.\right.$ )

$(\mathrm{CO})_{2} \mathrm{Cl}_{\mathrm{BBF}}$ ) (trans-2f, $\mathrm{C}_{23} \mathrm{H}_{41} \mathrm{BClF}_{4} \mathrm{FeN}_{3} \mathrm{O}_{2} \mathrm{P}_{2}$ )

This complex was prepared analogously to trans-2e with $150 \mathrm{mg}$ cis/trans $-\mathbf{1 f}(0.29 \mathrm{mmol})$ and $56 \mathrm{mg} \quad \mathrm{AgBF}_{4}$ $(0.29 \mathrm{mmol})$ as starting materials. Yield: $131 \mathrm{mg}(75 \%)$; ${ }^{1} \mathrm{H}$ NMR $\left(\mathrm{CD}_{2} \mathrm{Cl}_{2}, 20{ }^{\circ} \mathrm{C}\right): \delta=7.54\left(\mathrm{t},{ }^{3} J_{H H}=8.2 \mathrm{~Hz}\right.$, $\left.1 \mathrm{H}, \mathrm{py}^{4}\right), 6.17\left(\mathrm{~d},{ }^{3} \mathrm{~J}_{\mathrm{HH}}=8.2 \mathrm{~Hz}, 2 \mathrm{H}, \mathrm{py}^{3,5}\right), 3.58(\mathrm{~m}, 4 \mathrm{H}$, $\left.\mathrm{NCH}_{2} \mathrm{CH}_{3}\right), 3.18\left(\mathrm{~m}, \mathrm{CH}\left(\mathrm{CH}_{3}\right)_{2}\right), 1.49-1.10(\mathrm{~m}, 30 \mathrm{H}$, $\left.\mathrm{NCH}_{2} \mathrm{CH}_{3}, \mathrm{CH}\left(\mathrm{CH}_{3}\right)_{2}\right)$ ppm; ${ }^{13} \mathrm{C}\left\{{ }^{1} \mathrm{H}\right\}$ NMR $\left(\mathrm{CD}_{2} \mathrm{Cl}_{2}\right.$, $\left.20{ }^{\circ} \mathrm{C}\right): \delta=211.8\left(\mathrm{t},{ }^{2} J_{C P}=24.8 \mathrm{~Hz}, C \mathrm{C}\right), 162.3(\mathrm{vt}$, $\left.{ }^{2} J_{C P}=6.9 \mathrm{~Hz}, \quad \mathrm{py}^{2,6}\right), \quad 142.4 \quad\left(\mathrm{~s}, \quad \mathrm{py}^{4}\right), \quad 101.2 \quad(\mathrm{vt}$, $\left.{ }^{3} J_{C P}=2.6 \mathrm{~Hz}, \quad \mathrm{py}{ }^{3,5}\right), 43.3\left(\mathrm{~s}, \mathrm{NCH}_{2} \mathrm{CH}_{3}\right), 31.4(\mathrm{vt}$, $\left.{ }^{1} J_{C P}=10.8 \mathrm{~Hz}, \mathrm{CH}\left(\mathrm{CH}_{3}\right)_{2}\right), 19.1\left(\mathrm{~s}, \mathrm{CH}\left(\mathrm{CH}_{3}\right)_{2}\right), 17.8(\mathrm{~s}$, $\left.\mathrm{CH}\left(\mathrm{CH}_{3}\right)_{2}\right), 13.0$ (s, $\left.\mathrm{NCH}_{2} \mathrm{CH}_{3}\right)$ ppm; ${ }^{31} \mathrm{P}\left\{{ }^{1} \mathrm{H}\right\} \quad \mathrm{NMR}$ $\left(\mathrm{CD}_{2} \mathrm{Cl}_{2}, 20^{\circ} \mathrm{C}\right): \delta=132.8 \mathrm{ppm}$; IR (ATR): $\bar{v}=2005$ $\left(v_{\mathrm{C}=\mathrm{O}}\right) \mathrm{cm}^{-1}$.

\section{$\mathrm{X}$-ray structure determination}

X-ray diffraction data of trans-2a, trans-2c, trans-2e, and trans-2f (CCDC entries 1015363 (trans-2a), 1469956 (trans-2c), 1469957 (trans-2e), 1469958 (trans-2f),) were collected at $T=100 \mathrm{~K}$ in a dry stream of nitrogen on Bruker Kappa APEX II diffractometer systems using graphite-monochromatized Mo- $K \alpha$ radiation $(\lambda=0.71073 \AA)$ and fine sliced $\varphi$ - and $\omega$-scans. Data were reduced to intensity values with SAINT and an absorption correction was applied with the multi-scan approach implemented in SADABS [9]. The structures of trans-2c, trans-2e, and trans-2f were solved by charge flipping using SUPERFLIP [10] and refined against with JANA2006 [11]. The structure of trans-2a was solved with direct methods and refined against $F 2$ with the SHELX software package [12]. Nonhydrogen atoms were refined anisotropically. The $\mathrm{H}$ atoms connected to $\mathrm{C}$ atoms were placed in calculated positions and thereafter refined as riding on the parent atoms. The $\mathrm{H}$ atoms of the amine functionalities were located in difference Fourier maps and freely refined. Molecular graphics were generated with the program MERCURY [13].

\section{Computational details}

Calculations were performed using the Gaussian 09 software package, and the OPBE functional without symmetry constraints as already described previously [14].

Acknowledgments Open access funding provided by TU Wien (TUW). Financial support by the Austrian Science Fund (FWF) is gratefully acknowledged (Project No. P28866-N34). The X-ray center of the Vienna University of Technology is acknowledged for financial support and for providing access to the single-crystal diffractometer. LFV acknowledges Fundação para a Ciência e Tecnologia, UID/QUI/ 00100/2013.

Open Access This article is distributed under the terms of the Creative Commons Attribution 4.0 International License (http:// creativecommons.org/licenses/by/4.0/), which permits unrestricted use, distribution, and reproduction in any medium, provided you give appropriate credit to the original author(s) and the source, provide a link to the Creative Commons license, and indicate if changes were made.

\section{References}

1. Benito-Garagorri D, Puchberger M, Mereiter K, Kirchner K (2008) Angew Chem Int Ed 47:9142 
2. Benito-Garagorri D, Alves LG, Puchberger M, Veiros LF, Calhorda MJ, Carvalho MD, Ferreira LP, Godinho M, Mereiter K, Kirchner K (2009) Organometallics 28:6902

3. Benito-Garagorri D, Kirchner K (2008) Acc Chem Res 41:201

4. Benito-Garagorri D, Alves LG, Veiros LF, Standfest-Hauser CM, Tanaka S, Mereiter K, Kirchner K (2010) Organometallics 29:4923

5. Alves L, Dazinger LG, Veiros LF, Kirchner K (2010) Eur J Inorg Chem 3160

6. Harvey JN (2007) Phys Chem Chem Phys 9:331

7. Perrin DD, Armarego WLF (1988) Purification of laboratory chemicals, 3rd edn. Pergamon Press, New York

8. Glatz M, Holzhacker C, Bichler B, Mastalir M, Stöger B, Mereiter K, Weil M, Veiros LF, Mösch-Zanetti NC, Kirchner K (2015) Eur J Inorg Chem 5053
9. Bruker computer programs (2012) APEX2, SAINT, and SADABS. Bruker AXS Inc, Madison

10. Palatinus L, Chapuis G (2007) J Appl Cryst 40:786

11. Petrríček V, Dušek M, Palatinus L (2006) JANA2006, the crystallographic computing system. Institute of Physics, Praha

12. Spek AL (2009) Acta Cryst D65:148

13. Macrae CF, Edgington PR, McCabe P, Pidcock E, Shields GP, Taylor R, Towler M, van de Streek J (2006) J Appl Cryst 39:453

14. Schröder-Holzhacker C, Stöger B, Pittenauer E, Allmaier G, Veiros LF, Kirchner K (2016) Monatsh Chem. doi:10.1007/ s00706-016-1731-9 